Viti iXII ${ }^{\text {te }}$ i Botimit, Nr.1-2,

Dhjetor 2020

\title{
KRIJIMI I SHTETEVE BALLKANIKE DHE SHQIPTARËT
}

\author{
Ndriçim Mehmeti* \\ * Departamenti i Edukimit dhe Anglishtes, Fakulteti i Shkencave Shoqërore, Albanian \\ Univeristy
}

Adresë kontakti: cimmehmeti@yahoo.com

\section{Përmbledhje}

Gadishulli ballkanik, deri në fund të shek. XIX ishte nën zotërimin e Perandorisë Osmane. Rrudhja e Perandorisë Osmane, luftërat e saj me Rusinë dhe ndërhyrja e Fuqive të Mëdha, bëri që dalëngadalë, osmanët të humbasin terrenin në Ballkan. Veç këtyre faktorëve të jashtëm, nuk ka dyshim se edhe vetë lëvizjet e brendshme të popujve të Ballkanit përshpejtuan humbjen e autoritetit osman. Duke u nisur që në njëzet vitet e para të shek. XIX, Serbia Mali i Zi, Greqia, Bullgaria dhe Shqipëria filluan të shfaqin hapur platformat e tyre politike, kulturore për krijimin e shteteve autonome dhe pse jo të pavarura nga Perandoria Osmane. Shekulli XIX, krijoi një sërë kushtesh të favorshme për lëvizjen kombëtare ballkanike: shthurja e marrëdhënieve feudale, lindja e një shtrese të re të borgjezisë, ndonëse paraqitej e dobët në pikëpamje ekonomike dhe politike, rënia e fuqisë së Perandorisë Osmane si dhe ndërhyra gjithnjë e më e madhe e Fuqive evropiane drejt Ballkanit. Në qendër të tyre fillimisht ishte lëvizja për arsim dhe kulturë kombëtare që u frymëzua nga Rilindja e hershme evropiane. Kombet ballkanike kësisoj kërkuan të veçoheshin përfundimisht nga ndikimi osman dhe t'i japin vendin që duhej gjuhës dhe kulturës së tyre që rrezikonte të humbiste vlerat e saj përballë pushtimit turk. I gjithë ky aksion arsimor dhe kulturor kishte tipare të njëjta për të gjithë; serbët, shqiptarët, malazezët, grekët dhe bullgarët.

Fjalë çelës: Gadishulli Ballkanik, kombe, sundimi osman

\section{CREATION OF THE BALKAN STATES AND ALBANIANS}

\section{Abstract}

The Balkan Peninsula, until the end of the century. XIX was under the rule of the Ottoman Empire. The collapse of the Ottoman Empire, its wars with Russia, and the intervention of the Great Powers caused the Ottomans to gradually lose ground in the Balkans. In addition 
Ndriçim Mehmeti

to these external factors, there is no doubt that the internal movements of the peoples of the Balkans themselves accelerated the loss of Ottoman authority. Starting from the first twenty years of the century. XIX, Serbia

Montenegro, Greece, Bulgaria and Albania began to openly display their political, cultural platforms for the creation of autonomous states and why not independent of the Ottoman Empire. The nineteenth century created a number of favorable conditions for the Balkan national movement: the disintegration of feudal relations, the birth of a new stratum of the bourgeoisie, although it appeared weak economically and politically, the decline of the Ottoman Empire and the increasing interference of the great European Powers towards the Balkans. At their center was originally the movement for national education and culture that was inspired by the early European Renaissance. The Balkan nations thus sought to finally secede from Ottoman influence and give way to their language and culture, which was in danger of losing its value in the face of Turkish occupation. All this educational action had the same features for everyone; Serbs, Albanians, Montenegrins, Greeks and Bulgarians.

Key words: Balkan Peninsula, nations, Ottoman rule

\section{Krijimi shteteve ballkanike dhe shqiptarët}

Kombet ballkanike në fillim të shek. XX, intensifikuan përpjekjet e tyre, që të hiqnin qafe njëherë e përgjithmonë pushtimin osman apo çdo ndikim sado të vogël të Perandorisë Osmane. Në qendër të tyre fillimisht ishte lëvizja për arsim dhe kulturë kombëtare që u frymëzua nga Rilindja e hershme evropiane. Kombet ballkanike kësisoj kërkuan të veçoheshin përfundimisht nga ndikimi osman dhe t'i japin vendin që duhej gjuhës dhe kulturës së tyre që rrezikonte të humbiste vlerat e saj përballë pushtimit turk. I gjithë ky aksion arsimor dhe kulturor kishte tipare të njëjta për të gjithë; serbët, shqiptarët, malazezët, grekët dhe bullgarët. Në të gjithë rajonin, ndjenja kombëtare filloi të hidhte rrënjë dhe të forcohej. Energjia e të gjithë patriotëve dhe nacionalistëve u kanalizua drejt formimit të ndjenjës kombëtare. Gjithsekush pati simbolet e veta historike, luftëtarë, mendimtarë të shquar, pjesëtarë të religjioneve fetare, të cilët frymëzuan një epokë të re në historinë e ballkanasve.

Pavarësisht këtyre përpjekjeve të përbashkëta, në rajon mungoi fryma e bashkëpunimit. Kjo aq shumë për mungesë të një vullneti të përbashkët, por edhe për mungesë të një vizioni të qartë të zhvillimit dhe perspektivës të përbashkët të rajonit. Më herët serbët dhe malazezët ishin të prirur të kërkonin mbrojtjen e Rusisë, Anglia u vu në mbrojtje të Greqisë, ndërsa 
KRIJIMI I SHTETEVE BALLKANIKE DHE SHQIPTARËT

Austro-Hungaria tregoi një interesim të pjesshëm për katolikët shqiptarë në veri të vendit. Lidhja e fatit të popujve të Ballkanit pas Fuqive të Mëdha i detyrohet një sërë faktorëve. Në një farë mënyre, kjo ishte një zgjidhje që e diktonte koha. Në pamundësi të krijimit të një fronti të përbashkët të ballkanasve kundër osmanëve, në kushtet e prapambetjes e ekonomike dhe sociale, në mungesën e aftësive drejtuese dhe politike për shtetin, ndjekja pas e një modeli evropian u pa si shpëtim.

Ballkani në tërësi dhe shqiptarët në veçanti patën një zgjim kombëtar të vonë. Idetë iluministe që tashmë ishin realizuar shekuj më parë në shtet evropiane zunë vend shumë vonë në këtë rajon. Pushtimi i gjatë osman, rivalitetet politike mes Fuqive të Mëdha, copëzimi i territoreve, krijuan pengesa të mëdha në rrugën drejt formimit të kombeve të pavarura. Megjithatë, në kontekstin historik në të cilat u zhvilluan këto lëvizje, Perandoria Osmane ishte në qendër. Në këtë këndvështrim popujve ballkanik u lindte e gjithë e drejta e tyre të kundërshtonin me të gjitha mjetet këtë regjim. Sundimi i gjatë osman kishte sjellë një veçim të madh në të gjitha aspektet e Ballkanit nga pjesa tjetër e Evropës. Ky rajon i Evropës kishte ngelur jashtë zhvillimeve të shumta të ndodhura në Evropë deri në atë periudhë, siç ishin: Rilindja evropiane, revolucioni industrial, ndryshimet politike nga absolutizmi deri në krijimin e regjimeve politike parlamentare e kështu me radhë. Për të arritur në këto zhvillime, duhej shumë mund dhe punë që të gjithë të kapnin kohën e humbur. Gjithsesi, duhet thënë se veprimi për zgjim kombëtar, shumë shpejt u kanalizua në platforma nacionaliste që tejkaluan çështjen kombëtare duke u bërë burim konflikti në të ardhmen e Ballkanit. Ndonëse u paramendua se nën shembullin e Evropës, do të ecej drejt krijimit të shteteve kombëtare, kjo ide u braktis shumë shpejt. Greqia që fitoi e para pavarësinë u lëkund mjaft në zhvillimet e brendshme të saj. Mbreti Othon i thirrur nga Gjermania, u përpoq të vendoste një model evropian në kushte e një shoqërie ballkanike. Rivalitete e brendshme, krijimi i grupimeve politike të mbështetura nga njëra apo tjetra fuqi evropiane, e kaluan vendin në trazira politike gjithnjë e më të mëdha. Kur vendi ishte përfshirë në kaos dhe probleme të shumta, Jan Koletisi, kryeministri i Greqisë, shpalli platformën nacionaliste të "Megali idesë”. " $A i$ tregoi territoret që duheshin marrë: Thesalia, Epiri, Maqedonia, Thraka, Ishujt jonianë, bregdeti perrëndimor i Anadollit, pra e gjithë Rumelia: jo vetëm territore etnikisht greke, por të gjitha ato territore ku kishte dominuar qytetërimi grek. Ky irredentizëm u bë baza e nacionalizmit grek deri në vitin 1922 ". ${ }^{\text {. }}$

Si kundërpërgjigje e kësaj platforme të nacionalizmit grek, serbët shpallën platformën e tyre “Naçertania”. Në një këndvështrim krahasues që të dyja këto platforma tejkalonin thjesht dëshirat për formimin e shteteve kombëtare. Që të dyja në vetvete kërkonin revanshin për 
Ndriçim Mehmeti

territore që ose i takonin si trashëgimi historike, ose ishin të domosdoshme nga pikëpamja ekonomike. Greqia e krijuar në vitin 1822, nuk zotëronte më shumë se pjesa kontinentale. Ky territor i jepte shumë pak shanse për të qenë i fuqishëm ekonomikisht apo të paktën të krijonte bazat e një ekonomie të fortë. Veç kësaj trashëgimia osmane në fushën e bujqësisë ishte tejet e prapambetur. Synimi i Greqisë për të zgjeruar territoret e saj ishte mëse i justifikueshëm në tokat që asaj i takonin siç ishin: Kreta, një pjesë e Thesalisë apo ishuj që mbaheshin nga Turqia apo Fuqitë e Mëdha. "Megaliideja" dhe "Naçertania", vunë në pikëpyetje serioze mundësinë e një bashkëpunimi më të gjerë mes popujve të rajonit. Ndërkaq edhe Mali i Zi nuk qëndroi mbrapa shteteve fqinje.

Malazezët vunë si synim Shkodrën. Ndërsa palët e sipërpërmendura kërkonin të shkrinin luftën për çlirim kombëtar me formimin e shteteve të tyre, në kufij që i tejkalonin të drejtat natyrore të kombësisë që përfaqësonin, shqiptarët e panë veten të kërcënuar si nga sundimi osman ashtu edhe nga programet e fqinjëve që kërkonin territore thjesht shqiptare. Nuk ka dyshim se krijoi një stepje të madhe mes shqiptarëve, se cila do të ishte rruga në kërkim të të drejtave të tyre. Shqiptarët sikundër fqinjët e tyre, përballoheshin me probleme edhe më të mëdha. Nëse në vendet e tjera të Ballkanit, programi i Rilindjes Kombëtare po konkretizohej me shkëputjen e disa të drejtave kombëtare, në Shqipëri, ky program u përpunua në mënyrë të qartë rreth viteve 30 të shek.XIX. Në të parashtrohej qartësisht shtyllat mbi të cilat do të mbështetej ky program: arsimi, të drejtat kombëtare dhe lufta politike dhe ajo e armatosur për fitimin e këtyre të drejtave, bashkimi i trojeve kombëtare në një shtet të vetëm. Problemi më parësor i shqiptarëve ishte gjuha dhe arsimi kombëtar. Në mungesë të saj, do të ishte e vështirë të krijoje një lëvizje kombëtare me një mbështetje të gjerë në popull. Në përpjekje të vazhdueshme për identitetin e tyre kombëtar, dhe të frymëzuar nga iluminizmi francez, intelektualë shqiptarë brenda dhe jashtë vendit u vunë në krye të Lëvizjes Kombëtare.

Rilindja Kombëtare Shqiptare ndonëse e vonuar në kohë, arriti të rigjallërojë ndjenjën kombëtare dhe të ngre në një nivel më të lartë luftën për liri dhe të drejta kombëtare. "Ndonëse dashuria për truallin e të parëve ishte diçka me rëndësi, veprimtarët e Rilindjes Kombëtare, përpiqeshin në radhë të parë nëpërmjet mbrojtjes së gjuhës për t'i ndërgjegjësuar shqiptarët se përbënin një komb më vete." ${ }^{2}$ Kjo lëvizje patriotike, grumbulloi rreth vetes të gjithë pa dallim feje. "Ishte e logjikshme që nacionalizmi shqiptar të lindte në një frymë tolerance; ai nuk mund të krijohej mbi bazën e besimit fetar, sepse i duhej që t'i bashkonte të gjithë njerëzit." 3 
KRIJIMI I SHTETEVE BALLKANIKE DHE SHQIPTARËT

Ky zgjim i shqiptarëve së bashku me veprimtarinë e Lidhjes Shqiptare të Prizrenit, bëri të mundur të nxirrte përfundimisht nga izolimi çështjen shqiptare dhe ta ndërkombëtarizonte atë. Në këtë mënyrë lindën e dhe simpatitë e para për shqiptarët në opinionin publik dhe në ambientet e politikës Evropiane. Nuk duhet harruar se Rilindja Kombëtare, i vuri vetes si detyrë parësore, zhvillimit e arsimit dhe ngritjen e shkollave kombëtare. Duhet pranuar fakti se shkollat e huaja në territoret shqiptare, luanin një rol propagandistik, varësisht se kujt vendi i përkisnin. Më së shumti mbizotëronin shkollat osmane pro në veri dhe në jug kishte jo pak shkolla serbe dhe greke. Arsimimi në këto shkolla, shoqërohej me një propagandë që vinte në rrezik, zbatimin e një programi kombëtar në trojet shqiptare. Nuk ka dyshim se shqiptarët nuk ishin nënshtetas të bindur të Perandorisë Osmane, apo që ndiqnin në mënyrë fanatike politikat osmane. Tentativa për t'i etiketuar në mënyrë të tillë shqiptarët, ka dashur t'i veçoj këta të fundit nga zhvillimet në Ballkan me qëllimin e vetëm, që fqinjët ta kishin më të lehtë të justifikonin shtrirjen dhe aneksimin e tokave shqiptare.

Nëse politika e vendeve ballkanike ka kusuret e veta në krijimin e një klime mosbesimi mes shqiptarëve dhe fqinjëve, jo pak tone negativiteti kishte edhe politika osmane në Shqipëri. Me një lehtësi gati të pabesueshme, fqinjët mund të hapnin shkolla laike e fetare në territoret shqiptare, ndërsa shqiptarit nuk i lihej asnjë mundësi për ta ushtruar këtë të drejtë. Madje, ndarja e shqiptarëve në myslimanë, ortodoks dhe katolik, për osmanët do të thoshte se kishim të bënim me popullsi turke, latine dhe greke. Këto etiketime ndonëse në dukje artificiale, e dëmtuan rëndë imazhin e shqiptarëve në sytë e Evropës. Marrëdhëniet që u krijuan në Ballkanin e shek.XIX, si rezultat i daljes së projekteve për ngritjen e shteteve kombëtare, nuk prodhuan asgjë më tepër se provokimin e krizave të njëpasnjëshme dhe luftërave. Të gjitha konfliktet patën në qendër ambicien e Fuqive evropiane (e në veçanti të Rusisë jo vetëm, për të treguar forcën ndaj Perandorisë Osmane, por edhe për zgjerim të ndikimit të saj në Azi dhe Evropë) si dhe dëshirën e Serbisë, Greqisë, Malit të zi dhe Bullgarisë për të përfituar sa më shumë nga Traktatet e Paqes që vinin pas lufte. Në kohën e shpërthimit të kryengritjes në Bosnjë dhe Hercegovinë në vitin 1876, ishte rasti që të krijohej një front $i$ përbashkët ballkanik, kundër Perandorisë Osmane. Ky rast nuk u shfrytëzua, pasi shqiptarët nuk e panë veten të gatshëm për hyrë në këtë luftë. Përpos një organizimi të brendshëm, ajo që shkaktoi tërheqjen e tyre ishin qëllimet e Serbisë dhe Malit të Zi. Si Beogradi dhe Cetina kërkuan ta shfrytëzojnë këtë rast në favor të interesave të tyre.

Kjo u pa qartë në bisedimet e paqes, kur Austro-Hungaria kërkoi që Serbisë t'i mohohej dalja në Adriatik dhe duke pranuar pjesërisht të drejtat kombëtare të shqiptarëve. Pavarësisht nga kjo, Beogradi, Athina dhe Cetinja, nuk u tërhoqën duke pritur të shfrytëzonin raste 
Ndriçim Mehmeti

të tjera për të vënë në jetë planet e tyre. Kur u nënshkrua traktati i paqes së Shën-Stefanit, Bullgaria dhe Serbia mbetën në njëfarë mënyre të kënaqura, ndërsa Greqia protestoi se nuk ishin marrë parasysh "kërkesat e saj legjitime". Kongresi i Berlinit që tentoi të korrigjoj të metat e Shën-Stefanit, s’bëri gjë tjetër veçse zemëroi në maksimum shqiptarët. Shqiptarëve si kishte mbetur gjë tjetër veçse të rrëmbenin armët për të treguar se vendi kishte zot. Vitet e Lidhjes Shqiptare të Prizrenit i dhanë një shtysë të madhe, zhvillimit dhe konsolidimit të ndjenjës kombëtare shqiptare. Tashmë ishin qartësuar gjithnjë e më tepër çfarë kërkonin shqiptarë dhe cili do të ishte qëndrimi i tyre për çdo padrejtësi. Vetë lufta e shqiptarëve, bindi në njëfarë mënyre kancelaritë e Evropës, se vetëm politika osmane nuk mund të vendoste për shqiptarët. Tanimë, ata ishin një faktor që nuk duhej të shpërfilleshin, në përpjekjet për të vendosur një paqe të brishtë në Ballkan. Nëse në strategjinë e Fuqive të Mëdha mbetej ende e nevojshme, mbajta në këmbë e Perandorisë Osmane, për popujt e Ballkanit kjo alternativë u bë gjithnjë e më e papranueshme. Ndonëse shqiptarët kishin treguar se kishin forca për të marrë në dorë fatet e tyre, kjo do të ishte e vështirë. Përballë shteteve ballkanike shumica e të cilave kishin fituar pavarësinë dhe kishin një mbështetje të fuqishme nga Fuqitë e Mëdha, shqiptarët do ta kishin vështirë.

Shqipërisë i mungonte një territor i unifikuar, forca të brendshme të gatshme për një aksion të gjerë politik dhe arsimor dhe së fundi nuk kishte një mbështetje të qartë të ndonjërës prej fuqive me peshë në Evropë. Nuk ka dyshim se ndër shqiptarët ekzistonte një ndjenjë patriotike e kultivuar që nga kohët e vjetra. Megjithatë në kushtet e reja të krijuara, kjo ndjenjë duhej të kanalizohej në mënyrë të atillë që t'i përgjigjej një aksioni politik të mirë menduar dhe me objektiva të qarta. Kur Kongresi i Berlinit vendosi për copëtimin e tokave shqiptare, kjo ndjenjë u rizgjua në mënyrë të vetvetishme.

Ndonëse Kongresi i Berlinit, shënoi fillimin e copëtimit të trojeve shqiptare, kjo nuk shdekurajoi shqiptarët drejt objektivit të tyre për një shtet autonom. Shpesh herë ka pasur një diskutim mes patriotëve në atë kohë dhe studiuesve në kohët e mëvonshme: A duhej të synohej autonomisë apo të kërkohej pavarësimi i Shqipërisë nga Perandoria Osmane? Kjo pyetje kërkon një analizë të gjerë mbi faktet, dokumentet e kohës e veçanërisht kontekstit politik në Ballkan e në Evropë. Rruga drejt autonomisë, ishte zgjidhja më e logjikshme që impononte koha. Nëse do të vrapohej drejt pavarësisë, pavarësisht dëshirës së mirë asaj do t'i mungonin disa elementë që do ta bënin atë të qenësishme dhe të vlefshme për shqiptarët. Në radhë të parë do t'i mundonte një territor paraprakisht i unifikuar shqiptar; mbështetja e Fuqive të Mëdha; mungesa e një zhvillimi ekonomik; mungesa e një arsimi kombëtar që do të çonte vetvetiu në forcimin e ndjenjës kombëtare, infrastruktura, kultura administrative etj. Por siç 
KRIJIMI I SHTETEVE BALLKANIKE DHE SHQIPTARËT

e përmendëm më lart, u pa me shumë rëndësi zhvillimi i arsimit dhe kulturës kombëtare.

Çështja e një gjuhe të përbashkët, mësimit dhe shkrimit të saj u kthye në një nga objektivat më madhor të Lëvizjes Kombëtare shqiptare. "Të gjithë kombet e civilizuar kanë qenë të civilizuar nga shkrimet në gjuhën e tyre. Çdo vend që nuk shkruan gjuhën e tij, dhe nuk ka vepra në të, është në terr e barbari. Dhe shqiptarët që nuk e shkruajnë gjuhën e tyre dhe që nuk kanë vepra të tanishme, në gjuhën e tyre janë në të njëjtën gjendje. "3 Ky synim i të gjithë patriotëve shqiptarë do të filloj të përshpejtohet për t'u jetësuar një platformë mbarëkombëtare në fillim të shek. XX. Dobësimi i pozitave të Perandorisë Osmane, shoqërohej me një presion gjithnjë e në rritje të shqiptarëve, për të drejta kombëtare. Kur Fuqitë e Mëdha shpallën se do të kryenin reforma në Maqedoni, edhe njëherë shqiptarët e ndjen veten të rrezikuar. Shqiptarët kërkonin që reformat të përfshinin të gjitha vilajetet shqiptare dhe jo një pjesë e tyre. Kjo politike e Fuqive të Mëdha, tregonte se ato nuk donin t'ia dinin në atë periudhë për integritetin e trevave shqiptare. Në fillim të shek. XX, rritja e lëvizjes kombëtare të popullsive në Maqedoni nga njëra anë dhe acarimi i marrëdhënieve mes shteteve ballkanike, e vendosi çështjen maqedonase në qendër të diplomacisë së Perandorisë Osmane dhe Fuqive të Mëdha të interesuara në rajon. Bullgari, Serbia dhe Greqia, synonin të përfitonin secila në interes të vet. Në një vend me popullsi mjaft heterogjene, serbë, shqiptare, bullgarë, grek, vlleh, gëlonin interesa dhe organizata në favor të njërës palë apo tjetrës. Shqiptarët ishin të vendosur në mënyrë të qartë në disa rajone, të cilat përfshiheshin në territorin e vilajetit të Manastirit. Në të vërtetë problemi i shqiptarëve nuk qëndronte në kundërshtimin e reformave në Maqedoni, porse cila do të ishte pozita e tyre në këto reforma.

Ndërsa Fuqitë e Mëdha e shikonin si një mundësi për të krijuar një zonë, e cila nuk do të fuqizonte një shtet të caktuar ballkanik. Ishte farë e qartë se kush do të zotëronte territorin maqedonas do të kontrollonte tërësisht Ballkanin. Leverdia e ekonomike dhe pozita strategjike e këtij rajoni, mund të çonte që cilido shtet ballkanik që do t'i lihej në dorë territori maqedonas të dilte jashtë kontrollit të Fuqive të Mëdha. Kjo mbase ka qenë arsyeja kryesore, që Fuqitë e Mëdha, nuk lejuan krijimin e Bullgarisë së madhe pas Traktatit të Shën-Stefanit. Edhe Greqia kishte kohë që kishte hedhur sytë drejt territorit maqedonas. Ajo pretendonte se kishte një numër të madh të bashkatdhetarëve të saj në Maqedoni, interesat e të cilave duhet të mbroheshin me çdo kusht. Në këtë vorbull kërkesash dhe pretendimesh hyri edhe Rumania. Ajo iu drejtua Portës së Lartë me kërkesën për njohjen e popullsisë vllehe në Maqedoni. "Qëllimet rumune qenë të qarta; shteti nuk mund të pretendonte realisht ndaj Maqedonisë apo të shpresonte të aneksonte ndonjë tokë atje. Qëllimi kryesor ishte të bllokonte Bullgarinë dhe të bënte të pamundshëm, krijimin e kufijve të Shën-Stefanit." 2 Për t'i paraprirë 
Ndriçim Mehmeti

situatave të pakëndshme që mund të krijoheshin por edhe nën presionin e Fuqive të Mëdha, "Stambolli shpalli në dhjetor 1902, "Udhëzimin mbi reformat në vilajetet e Turqisë evropiane". ${ }^{3}$ Kjo shpallje dhe mungesa e veprimit për zbatim të reformave, i la të pakënaqura Rusinë dhe Austro-Hungarinë. Për t'i shkuar deri në fund kësaj çështje, "Vjena dhe Petërburgu, paraqitën jo më vonë se në shkurt 1903 një projekt të parë të programit të "tre vilajeteve Selanikut, Kosovës dhe Manastirit”. ${ }^{4}$

Ajo që bie në sy në këtë projekt drejtuar Portës së Lartë, është trajtimi që i bëhet shqiptarëve. "Kryengritësit shqiptar cilësoheshin si përgjegjësit kryesor të turbullirave në të tre vilajetet e Maqedonisë". ${ }^{5} \mathrm{Një} \mathrm{cilësim} \mathrm{i} \mathrm{tillë} \mathrm{për} \mathrm{shqiptarët} \mathrm{tregonte} \mathrm{se} \mathrm{ata} \mathrm{nuk} \mathrm{do} \mathrm{të}$ ishin pjesë e zgjidhjes së problemit. Kjo vinte edhe njëherë në rrezik çështjen shqiptare. Të paktën në vilajetin e Kosovës dhe në atë të Manastirit, shqiptarët ishin në shumicë. Shmangja e tyre do të thoshte se, zgjidhja e çështjes maqedonase do të qe e cunguar dhe jo afatgjatë. Për fat të mirë, projekti austro-rus nuk gjeti përkrahjen e Portës së Lartë. "Porta nuk e pranoi duke e quajtur si një përçarje të izoluar të dy fuqive në punët e brendshme të Turqisë". ${ }^{6}$ Mesa duket Stambolli veç të tjerave, i trembej një rebelimi të shqiptarëve, i cili, mund ta vinte në një pozitë të vështirë. Pavarësisht, se Porta e Lartë nuk e pranoi projektin e shkurtit 1903 të paraqitur nga Austro-Hungaria dhe Rusia, që të dyja këmbëngulën në realizimin e një projekti reformash në Maqedoni. Më së fundi qeveria e "Stambollit dha miratimin e saj në nëntor 1903." 6

Një nga pikat më problematike të marrëveshjes së re, ishte ndarja e re administrative që duhej të merrte parasysh kriterin etnik. Ky qe rasti më i mirë për Serbinë, Bullgarinë dhe Greqinë, të cilat pa vonesë shpallën statistikat e tyre. Kush e kush më parë, filloi të pretendoj se kishte shumicën në rajonin maqedonas. Kjo situatë provokoi reagim ndër shqiptarët e Kosovës. Fillimisht ishin ata të parët, të cilët ngritën krye për të kundërshtuar reformat maqedonase. Shpërfillja që iu bë elementit shqiptar ishte e papranueshme për ta. Në këtë rast ata kërkonin që reforma të ngjashme duhet të përfshinin të gjithë territoret shqiptare. Kërkesa për zbatim të reformave në Maqedoni, ndeshi edhe në reagimin e Italisë. Politika italiane, filloi të hedhë shikimin drejt Ballkanit e veçanërisht drejt Shqipërisë. Duke parë tendencat e shteteve ballkanike, asaj natyrshëm i ka lindur shqetësimi se këto mund të vinin në rrezik planet e saj strategjike për kontrollin e Adriatikut. Për të konkretizuar qëndrimin e saj, “në prill 1903 qeveria e Romës i pati propozuar asaj të Vjenës një aksion të përbashkët diplomatik për të hartuar edhe për Shqipërinë një program reformash pak a shumë të njëllojta me ato që Austro-Hungaria po përpiqeshin të përpunonin për Maqedoninë." 7 Vjena nuk e mirëpriti këtë propozim, por megjithatë ajo ndryshoi qëndrim nga projekti i shkurtit të vitit 1903. 
KRIJIMI I SHTETEVE BALLKANIKE DHE SHQIPTARËT

Madje, Austro-Hungaria kërkoi që nga reformat të përjashtoheshin, veç vilajeteve të Kosovës, Shkodrës dhe Janinës, edhe krahinat shqiptare të vilajetit të Manastirit. Ndonëse ky qëndrim nuk i jepte një zgjidhje çështjes shqiptare, të paktën nuk e përziente atë me reformat maqedonase, rrjedhojat e të cilave mund të ishin të paparashikuara. Për shqiptarët ky ishte një sukses, por që nuk u pasua nga hapa të mëtejshme, drejt ndërkombëtarizimit të çështjes së tyre. Dukej qartë se ndërhyrja italiane kishte nervozuar qarqet diplomatike të Vjenës dhe kishte ndikuar sadopak në ndryshimin e qëndrimit të saj për Shqipërinë. Vjena ende nuk ishte e gatshme të ndante zonat e influencës në Ballkan me italianët, ndërkohë që nuk mund t'i linte Romës, ekskluzivitetin mbi çështjen shqiptare. Megjithatë gjatë vitit 1904, dukej se tensioni midis dy fuqive filloi të bie. Një shenjë e vullnetit të mirë, ishte pranimi nga ana e Austro-Hungarisë e një gjenerali italian që do të udhëhiqte forcën e xhandarmërisë në Maqedoni. Në takimin mes dy ministrave të jashtëm të Italisë Tittoni dhe atij të Austro-Hungarisë, Guduhovski, u ra dakord në parim se asnjëra prej fuqive nuk synonte në një të ardhme të afërt, territorin shqiptar. "Përsa i përket Shqipërisë, Tittoni deklaroi se "edhe Roma nuk kishte ndonjë synim mbi të” dhe dëshironte që tërësia e saj të respektohej nga të gjithë”. ${ }^{7} \mathrm{E}$ thënë ndryshe të dyja fuqitë kërkonin ruajtjen e statukuo-së, në pamundësi për të rënë dakord në ndarjen e zonave të ndikimit në territoret shqiptare. Përveç këtij takimi në vitin 1905, Vjena dhe Roma shkuan edhe më tej. Në rast se prishej statukuo-ja në Ballkan, ato “do të përpiqeshin për zbatimin e parimit të kombësisë në Gadishullin Ballkanik në bazë të kombësisë”. ${ }^{8}$ Ndonëse si Italia ashtu edhe Austro-Hungaria ende nuk ishin të gatshme për shpërbërjen e Perandorisë Osmane, me pohimin e mësipërm, ato nuk dëshironin që asnjë prej shteteve të Ballkanit të merrte më shumë fuqi nga ç’ka i takonte. Në një farë mënyre, nëse do të ruhej ky parim, padyshim që çështja shqiptare dilte e fituar. Megjithatë duhej parë sesi do të rridhnin ngjarjet e mëvonshme, ç'ka në Ballkan ishte e vështirë të parashikohej. Përkundër këtyre qëndrimeve të Fuqive të Mëdha, shtetet ballkanike lëvizën drejt aleancave që mund të siguronin më shumë hapësira për ta. Në vitin 1904, Serbia dhe Bullgaria nënshkruan një traktat aleance. Traktati përfundonte më një protokoll të veçantë që parashikonte, veç të tjerash edhe të ardhmen e Shqipërisë. Sipas këtij protokolli, "Shqipëria kufizohej nga Shkodra në Janinë. Në rast se ngrihej çështja e Shqipërisë, të dyja palët do të përkrahnin një zgjidhje që do të favorizonte interesat e Malit të $Z i{ }^{\prime \prime} .{ }^{9}$ Me pak fjalë, protokolli hidhte bazat e një copëtimi të Shqipërisë, që pak a shumë nuk do të ruante as kufijtë e sotëm. Në këtë rast Serbia dhe Bullgaria mendoni t'i jepnin Ballkanit një dominim të plotë të sllavëve në rajon. Në vitet e ardhshme, do të kishte projekte të tjera që më shumti vareshin nga marrëdhëniet e krijuara mes shteteve ballkanike, apo nga qëndrimi i Fuqive të Mëdha dhe duke marrë gjithnjë në konsideratë edhe pozitën e Perandorisë Osmane. 
Ndriçim Mehmeti

Në rastin kur në skenë doli çështja boshnjake, Austro-Hungaria rimodeloi qëndrimin e saj ndaj shteteve ballkanike në tërësi dhe çështjes shqiptare në veçanti. Në vitin 1908, i cili, përkoi edhe me revolucionin xhonturk, ministri i jashtëm austro-hungarez, Erentali shfaqi një tjetër projekt. Duke dashur të izolojnë tërësisht Serbinë, Erentali e parashikonte në këtë mënyrë të ardhmen në Ballkan. "Ne do të mund të kishim-thoshte ai- një Shqipëri të pavarur nën suazën tonë, një Mal të Zi që do të varej nga dëshira jonë e mirë dhe një Bullgari të madhe të lidhur me ne nga mirënjohja e thellë’. ${ }^{10} \mathrm{Ky}$ projekt i Austro-Hungarisë, jo vetëm që nuk merrte parasysh interesat e Serbisë, por gati e mënjanonte përfundimisht nga çdo ndarje në Ballkan të trashëgimisë së Perandorisë Osmane. Serbia ktheu sytë nga Rusia. Ndonëse fillimisht qeveria serbe i bëri rezistencë, Austro-Hungarisë, ajo u detyrua të tërhiqet "kur Rusia e pranoi aneksimin, pasi mori një ultimatum të vërtetë nga Berlini”. ${ }^{11}$

Ky rikonfigurim i ri i Ballkanit, propozuar nga Austro-Hungaria, ndonëse për shqiptarët ishte një sinjal pozitiv, nuk do të kapërdihej lehtë nga Serbia. Mbase këtu i ka rrënjët armiqësia e thellë mes Vjenës e Beogradit që do të çonte më vonë në ngjarjen e Sarajevës më 1914. Ndërkohë që zhvilloheshin këto ngjarje në rrafshin diplomatik, në ambientin politik të Perandorisë Osmane, xhonturqit po fitonin gjithnjë e më shumë terren. Në këtë situatë të krijuar në vitet 1908-1909, shqiptarët e shfrytëzuan në favor të tyre. Me një shpejtësi të rrufeshme u përhap një rrjet i gjerë i klubeve patriotike, në vend. Ndonëse në pamje të parë ato kujdeseshin për çështjet e arsimit, në to punohej në tërësi për çështjen kombëtare. Vendimet e Kongresit të Manastirit dhe Kongresit të Elbasanit ishin një hap i sigurt drejt ngritjes së ngrehinës së munguar të kulturës shqiptare. Shkolla shqipe tanimë po vendosej në shinat e duhura dhe askush nuk mund të mendonte se do të kishte më kthim prapa. Ishte momenti që dukej se koha po punonte për shqiptarët. Veprimi aktiv i tyre i kaloi kufijtë e vendit, kur në Ferizaj 10 mijë vetë, protestuan të armatosur dhe i kërkuan sulltanit të shpallte kushtetutën, përndryshe rebelimi do të shkonte deri në portat e Stambollit. I zënë ngushtë nga kjo lëvizje, Sulltani s’bëri gjë tjetër veçse shpalli kushtetutën. Shqiptarët shpresuan shumë se fillimi i një jete konstitucionale, në Perandorinë Osmane do të mundësonte marrjen e më shumë të drejtave kombëtare. Padyshim që qëllimi final do të ishte krijimi i një shteti autonom shqiptar brenda suazës së Perandorisë Osmane. Entuziazmi i shqiptarëve do të shuhej shumë shpejt. Turqit e rinj u treguan po aq naivë në politikë sa osmanët e vjetër. Përveç faktorit shqiptar që ishte më i interesuari në Ballkan për lëvizjen xhonturke, shtetet e tjera, nuk shfaqën ndonjë simpati të veçantë.

Përkundrazi, Greqia dhe Bullgaria ndërmorën përpjekje për të përfituar nga situata. Greqia e cila nuk kishte hequr dorë nga pretendimet mbi Shqipërinë e Jugut, që nga Traktati 
KRIJIMI I SHTETEVE BALLKANIKE DHE SHQIPTARËT

i Berlinit, rishfaqi dëshirën për të aneksuar këto toka. Ndërkaq, “Bullgaria që kishte frikë se mos Turqia mund të përpiqej të ripohonte autoritetin e saj në këtë vend, shpalli pavarësinë e plotë më 5 tetor 1908”. ${ }^{12}$ E gjithë situata politike në Ballkan në vitin 1908, u ndërlikua akoma më shumë, nga aneksimi që Austro-Hungaria i bëri Bosnjës dhe Hercegovinës. Është e vështirë të shprehemi në pak reshta nëse ky ishte veprimi më i duhur i Monarkisë Dualiste, por një gjë mund të thuhet me siguri: Aneksimi shtyu gjithnjë e më shumë ndjenjat e shteteve të Ballkanit drejt një lufte. Serbia nuk do të pajtohej kurrë me faktin që Austro-Hungaria të ishte në kufi me të, Bullgaria pas marrjes së pavarësisë mund të provokonte një luftë tjetër kundër Perandorisë Osmane, për të arritur qëllimet e saj, ndërsa Mali i Zi dhe Greqia do të orientoheshin sipas situatës.

Në këto rrethana, shqiptarët ishin gjithnjë e më të rrezikuar. Politika xhonturke me kokëfortësinë e saj, jo vetëm që nuk asnjë lëshim ndaj shqiptarëve por në të kundërt iu përgjigj me represion çdo kërkese të shqiptarëve. Kjo shkaktoi një varg revoltash që nga viti 1909 deri në vitin 1912. Periudha 1910-1912, ishte parathënia e përgatitjes së shqiptarëve në kërkim të zgjidhjes së çështjes kombëtare. Reagimi i armatosur i shqiptarëve, në një farë mënyre i gjeti të papërgatitur si vendet ballkanike ashtu edhe Fuqitë e Mëdha. Tashmë krahas krizës boshnjake, çështjes maqedonase, ngrihej edhe problemi i shqiptarëve. Një lëvizje e shqiptarëve ishte paralajmëruar prej vitesh, por ndoshta Fuqitë e Mëdha besonin se Porta e Lartë do të mund ta vinte nën kontroll aksionin e shqiptarëve. Nga ana tjetër vetë Fuqitë e Mëdha ishin të pavendosura për çështjen shqiptare. Austro-Hungaria kishte një qëndrim të dyzuar, Rusia duke mbështetur Serbinë e Malin e Zi, nuk e njihte këtë çështje, Gjermania qëndronte larg problemeve të Ballkanit, ndërsa Anglia luante rolin e arbitrit, në varësi të situatës. Shtetet ballkanike u shqetësuan nga lëvizja e shqiptarëve dhe vëzhgonin me kujdes, deri ku do të arrihej. Mali i Zi, shpejtoi t’i japë përkrahje kryengritjes së shqiptarëve të vitit 1910. Pjesëmarrja aktive e malazezëve shkoi deri aty sa, "Gjenerali Janko Vukotiç, kushëri $i$ mbretëreshës së Malit të Zi drejtonte operacionet jozyrtarisht”. ${ }^{13}$ Mali i Zi shpresonte se përmes luftës së shqiptarëve, t’i jepej një grusht dërmues Perandorisë Osmane. Pas kësaj shtetet ballkanike do ta kishin shumë më të lehtë fitoren ndaj ushtrisë osmane. Fqinjët e Shqipërisë mund të kenë arsyetuar edhe në një mënyrë tjetër: për ta rebelimi i shqiptarëve ndaj Portës së Lartë, pakësonte shanset e bashkimit të shqiptarëve me osmanët ndaj ushtrive të tyre. Megjithatë duhet pranuar fakti se pak shumë nga shqiptarët kishin menduar në këtë mënyrë. Shqiptarët u rebeluan si pasojë e politikës osmane dhe në kërkim të të drejtave të mohuara. Ata ishin i vetmi popull në Ballkan që i mungonin këto të drejta prej shekujsh. Këtu fillonte dhe mbaronte papajtueshmëria e tyre me politikën xhonturke. Nëse shqiptarët 
Ndriçim Mehmeti

mbështetën revolucionin xhonturk, kjo nuk u bë thjesht për faktin se ata ishin pro-turq në ndjenjën e tyre. Ata shpresuan sesi mirënjohje do të mund të realizonin qëllimet e tyre kombëtare. Është e gabuar të mendohet se shqiptarët ishin të paaftë për të qeverisur, apo për të fituar të drejtat e tyre. Akoma më i padrejtë do të ishte mendimi se ata qëndruan deri në fund me Perandorinë Osmane, si rezultat i fesë apo i lidhjeve ekonomike me të. Përkundrazi, nëse shtetet ballkanike do të kishin afruar shqiptarët një pakt kundër Portës së Lartë, duke respektuar të drejtat kombëtare të secilit popull, ato do të gjenin një aleat të vlefshëm në krah të tyre. Lënia pas dore e faktorit shqiptar si nga aleatët ballkanik dhe nga Fuqitë e Mëdha, do të rezultonte në vitet e mëvonshme si një manovër e gabuar politike. Ishte kjo arsyeja që edhe pse të papërgatitur për një pavarësi të plotë, në rrethanat e krijuara patriotët shqiptar, menduan se zgjidhja e problemit të tyre mund të vinte me shpalljen e pavarësisë.

\section{Referenca}

Castellan.G., “Historia e Ballkanit, Tiranë, 1996, f.67-68

1. Jascques E, Shqiptarët, Tiranë, 1995, f.32-33.

2. Metais Sergei, "Histori e Shqiptarëve”, Tiranë, 2001, f.26-27

3. Skëndi.S., "Zgjimi kombëtar i shqiptarëve”, Tiranë 2000, f.39-41

4. Charles dhe Barbara Jelaviç, "Krijimi i shteteve kombëtare të Ballkanit, 1804-1920", Tiranë, 2004, f.81-82.

5. Puto.A., "Historia diplomatike e çështjes shqiptare”, Tiranë, 2003, 52-53.

6. Puto. A. "Historia diplomatike e çwshtjes shqiptare”, Tiranë, 2003, 23-24.

7. Puto. A. "Historia diplomatike e çwshtjes shqiptare", Tiranë, 2003, 23-24.

8. Puto. A. "Historia diplomatike e çwshtjes shqiptare", Tiranë, 2003, 32-33

9. Puto. A. "Historia diplomatike e çwshtjes shqiptare", Tiranë, 2003, 46-4

10.Puto. A. "Historia diplomatike e çwshtjes shqiptare", Tiranë, 2003, 65-66.

11. Puto. A. "Historia diplomatike e çwshtjes shqiptare", Tiranë, 2003, 82-84.

12. Swire.J., "Shqipëria ngritja e një mbretërie”, Tiranë, 2005, f.62-64. 